\title{
«DEJARLO TODO POR DIOS, ES COMPRAR EL CIELO»: EL VOTO DE POBREZA, LA MENDICIDAD Y EL ASISTENCIALISMO ENTRE LOS DOMINICOS CASTELLANOS (1460-1550)
}

\author{
POR \\ GUILLERMO NIEVA OCAMPO \\ Universidad del Norte Santo Tomás de Aquino
}

\section{RESUMEN}

En tiempos de la reforma, gracias a una coyuntura favorable, los conventos dominicos castellanos experimentaron un fuerte acrecentamiento de su patrimonio. Los superiores conventuales consideraron necesaria la posesión de esos bienes para el mantenimiento de la comunidad y subsistencia de unos frailes eminentemente intelectuales. A su vez, el embellecimiento y la ampliación del recinto de los conventos, en una época que pregonaba la estricta pobreza, fue deudora de una valoración sagrada otorgada al edificio. Sin embargo, esos mismos prelados hicieron un esfuerzo ingente por asegurarse que el fraile fuera consciente que el voto de pobreza lo convertía, a título personal, en un pobre. Por otra parte, la espiritualidad de los dominicos consideró a los pobres -a los que asoció con Cristo- como un medio redentor, de allí la práctica de la limosna.

PALABRAS CLAVE: Dominicos, reforma, voto de pobreza, pobres.

\section{«LEAVE EVERYTHING TO GOD, IS TO BUY THE SKY: THE VOW OF POVERTY, BEGGING AND CARE AMONG DOMINICAN CASTELLANOS (1460-1550)}

\begin{abstract}
In the days of the reform, the Castilian Dominican convents experienced a strong increase of their patrimony, thanks to a favorable conjuncture. The superiors of those Convents considered that the possession of such goods was necessary for the maintenance of the community and subsistence of friars that
\end{abstract}


were eminently intellectual. The embellishment and expansion of the convents' areas, in turn, at a time when strict poverty was proclaimed, were due to the sacred value granted to the building. Nevertheless, those same prelates made an enormous effort to make sure that the friar was conscious that the vow of poverty turned him, in personal terms, into a poor man. On the other hand, the spirituality of the Dominicans considered the poor -who were associated with Christ- as a redemptive means, which led to the practice of alms.

KEY WORDS: Dominicans, Reform, vow of poverty, the poor.

Recibido/Received 03-01-2008

Aceptado/Accepted 26-05-2008

El movimiento de reforma recibe tópicamente el nombre de observancia. Tal término deriva de la tendencia fundamental y esencial de la reforma que perseguía -sobre todo entre los Mendicantes- la observantia ad normam Regulae o la regularis observantia o bien la strica observantia regularis, reaccionando contra la relajación o decadencia introducida en la vida de los conventos. La acción de este movimiento se estructuró bajo la forma de «congregaciones» o formas jurídicas similares. A diferencia de las órdenes monásticas, cuyas congregaciones significaron verdaderas modifi-caciones institucionales, entre los Mendicantes -nacidos según una estructura centra-lizada y orgánica- las congregaciones de la reforma constituyeron una reproducción casi completa del gobierno provincial. Por lo cual, desarrollaron sus funciones dentro de la orden con amplia autonomía respecto a los superiores provinciales, mientras quedaban bajo jurisdicción de las autoridades generalicias. En el caso de las congregaciones dominicas, estas nunca llegaron a ser de derecho pontificio (o sea, a estar bajo la jurisdicción de los Papas, desconociendo las autoridades de la propia orden) como sucedió con las franciscanas ${ }^{1}$.

Dadas estas características, la reforma de los regulares a lo largo de los siglos XV y XVI fue ante todo un tiempo de ruptura en la historia de las comunidades religiosas durante el cual se enfrentaron, a veces violentamente, observantes y conventuales ${ }^{2}$. Por ende, la actividad reformista fue un estado, pero

\footnotetext{
${ }^{1}$ Respecto a las características principales de las congregaciones de observancia véase Mario FoIs, «Osservanza-Congregazioni di Osservanza», en Dizionario degli Istituti di Perfezione (DIP), VI, Roma 1980, col. 1036-1057. Sobre la reforma de los dominicos y el enfrentamiento entre la Congregación de la reforma y la Provincia véase el clásico trabajo de V. Beltrán de Heredia, Historia de la reforma de la provincia de España, Roma, 1939.

${ }^{2}$ Tal como lo ponen en evidencia diversos estudios sobre la reforma de los religiosos, la violencia ejercida sobre las comunidades religiosas para forzar su reformación y la dudosa inobservancia de las reglas y normas entre los conventuales caracterizaron la acción de los reformistas. Numerosos estudiosos coinciden en que la reforma fue más una exigencia de los laicos que una necesidad de los mismos religiosos. Los agentes directos de la reforma, los reformadores, serían en general laicos que entraron a la vida religiosa a una edad avanzada y, por lo tanto, eran portadores de una concepción elaborada con antelación de la vida en los claustros. La reforma fue un fenómeno reticular que involucra a miembros
}

Hispania Sacra, LXI

124, julio-diciembre 2009, 483-512, ISSN: 0018-215-X 
también un momento generador de conflictos y revelador de tensiones que generalmente excedieron el ámbito estrictamente eclesiástico ${ }^{3}$.

En Castilla, si bien la fundación del convento reformado de Escalaceli en 1423, realizada por fray Álvaro de Córdoba -confesor hasta 1409 de la reina Catalina de Láncaster4- así como las actas del Capítulo Provincial de 1434, reflejan la tendencia reformista general de la Orden, la acción del movimiento observante como tal se inició recién hacia $1460^{5}$. En efecto, la actividad reformista de fray Álvaro fue un fenómeno aislado, más bien tolerado por la Provincia, cercano al eremitismo, que finalmente se circunscribió a la comunidad de Escalaceli, así como al convento de Murcia -fundado por fray Juan de Murciay a unas pocas comunidades más ${ }^{6}$. Por lo tanto, no fue en las ciudades de Anda-

de la jerarquía eclesiástica, de la nobleza y a la monarquía misma. Véase Marie Dominique CHENU, «L'Humanisme et la Réforme au Collège de Saint-Jacques de Paris», Archives d'Historie Dominicaine, 1 (1946), pp. 130-154; Elisabeth LóPEZ, «L'observance franciscaine et la politique religieuse des Ducs de Bourgogne», Annales de Bourgogne, 72 (2000), pp. 73-103 y 177-236; John Thomson, The Early Tudor Church, Londres, 1993; G. FERNÁNDEZ GALLARDO, La supresión de los franciscanos conventuales de España en el marco de la política religiosa de Felipe II, Madrid, 1999; Francisco Javier RoJo ALIQUE, «Reforma religiosa, sociedad y política en la Baja Edad Media: el ejemplo de San Francisco de Palencia en el siglo XV», Hispania Sacra vol. LIX, n 120 (2007), pp. 469-491; Alfonso D’AmATo, «Vicende dell'Osservanza regolare nella congregazione domenicana di Lombardia negli anni 14691472», Archivum Fratrum Praedicatorum, 15 (1945), 52-101.

3 Además de los clásicos estudios de referencia como J. GARCía ORO, La reforma de los religiosos españoles en tiempo de los Reyes Católicos, Valladolid, 1969; M. Jones, La Contrarreforma. Religión y sociedad en la Europa moderna, Madrid, 2003, pp. 34-53; véase también, Kaspar ELM, «Riforme e Osservanza nel XIV e XV secolo», en Il Rinnovamento del Francescanesimo l'Osservanza. Atti dell'XI Convegno Internazionale, Assisi, 20-21-22 ottobre 1983, Assisi, 1985, pp. 149-167; G. CHITTOLINI y K. ELM, Ordini religiosi e societá politica in Italia e Germania nei secoli XIV e XV, Bologna, 2002, pp. 729; Adeline RUCQUOI, «La réforme monastique en Castille au XVe siècle: une affaire sociale», en Horizons marins, itinéraires spirituels (Ve-XVIIIe siècles), I: Mentalités et sociétés, Paris, 1987, pp. 239253; J.-M., Le Gall, Les moines au temps des réformes, France (1480-1560), Paris, 2001; Frédéric MEYER - Louis VIALLET, «Le champs du possible. Jalons pour une enquête», Identités franciscaines à l'âge des réformes, Chambéry-Annecy, 2005, pp. 13-31.

${ }^{4}$ Por instigación de don Fernando de Antequera, la influyente Leonor López de Córdoba -hermana de fray Álvaro- había sido apartada de la corte de la reina en 1409. Junto a ella fueron extrañados todos sus parientes. Véase, A. EchEVARría, Catalina de Láncaster, Hondarribia, 2002, pp. 124-131.

${ }^{5}$ El texto completo de las actas del Capítulo Provincial de 1434, precedido por un estudio de los inicios de la reforma de la Orden, se halla en Ramón HERnÁNDEZ, «La reforma dominicana entre los Concilios de Constanza y Basilea», Archivo Dominicano, VIII (1987), pp. 5-50.

6 Véase, Álvaro Huerga, Escalaceli, Salamanca, Universidad Pontifica, 1981; Vicente BELTRÁN DE HeREDIA, «Los comienzos de la reforma dominicana en Castilla, particularmente en el convento de San Esteban de Salamanca y su irradiación a la Provincia de Portugal», Archivum Fratrum Praedicatorum, 28 (1958), pp. 221-262. Un trabajo más amplio y actual sobre los Mendicantes en Andalucía a finales de la Edad Media, que aborda el origen y la vinculación social de los frailes y monjas, en J. M. MiURA ANDRADES, Frailes, monjas y conventos: las órdenes mendicantes y la sociedad sevillana bajomedieval, Sevilla, 1998. 
lucía donde se originó la reforma, sino más bien en aquellas cercanas al centro de poder del reino, o sea, en las ciudades castellanas.

El cardenal Juan de Torquemada, que desde Roma se había encargado de la reforma de algunos monasterios benedictinos italianos y castellanos, así como de la incorporación del convento dominico de Santa María Sopraminerva a la Congregación de Lombardía, dio inicio al reformismo dominico castellano con la reforma del convento de San Pablo de Valladolid. Deudor de una pedagogía de la ejemplaridad que había asimilado durante su estancia en Basilea en contacto con los seguidores de fray Juan Nider, Torquemada estaba convencido que una verdadera reforma de la cristiandad debía partir de una reforma del clero, pero no sólo de su cabeza -como habían sostenido los conciliaristas- sino de todos sus miembros ${ }^{7}$.

Para reformar a los frailes de Valladolid, Torquemada tras haber conseguido la autorización correspondiente del Papa y del Maestro general de la Orden, utilizó al benedictino Juan de Gumiel prior de San Benito. La reforma del convento no fue pacífica, ya que los frailes resistieron a los reformadores por considerar que estos violaban los derechos electivos del capítulo conventual, al instituir autoridades extrañas al convento y a la Orden. A fin de fortalecer la posición de Gumiel y completar así el cambio, Torquemada obtuvo un privilegio de la Santa Sede que desvinculó a los frailes vallisoletanos de la autoridad del provincial ${ }^{8}$.

Sabemos que algunos reformadores habían sido sostenidos e incluso solicitados por las poblaciones vecinas a alguna abadía ${ }^{9}$. Sin embargo, en el caso de los dominicos, el inventario de los índices de impopularidad de los reformadores se revela más fructuoso que aquellos que testimonian el apoyo popular. De hecho, se observa con mucha frecuencia actos de solidaridad entre la población y los claustrales ${ }^{10}$.

${ }^{7}$ Sobre el pensamiento y la actividad reformista de Torquemada véase, Karl BINDER, «El cardenal Juan de Torquemada y el movimiento de Reforma Eclesiástica en el siglo XV», Revista de Teología, n 3 (1953), pp. 42-66.

${ }^{8}$ Fragmento de una carta del prior de San Benito de Valladolid al cardenal Torquemada, 16 de enero de 1463. Archivo Histórico Nacional (A.H.N.), Clero, Valladolid, leg. 449.

${ }^{9} \mathrm{El}$ proceso general de la reforma de los religiosos en Castilla ha sido estudiado por J. GARCíA ORo, La reforma de los religiosos españoles en tiempo de los Reyes Católicos, Valladolid, Instituto Isabel la Católica, 1969. Una síntesis reciente en Margarita CANTERA MONTENEGRO, «Las órdenes religiosas», en M. A., LADERo QuesAdA, El mundo social de Isabel la Católica, Madrid, 2004, pp. 113-126.

10 Tal como sucedió en el caso del convento de San Esteban de Salamanca que logró expulsar, con la ayuda de los miembros del bando de San Benito, a los reformadores que intentaron incorporar el convento a la congregación de la reforma en 1475. El convento se incorporó a la Congregación recién en 1486. Véase J. Cuervo, Historiadores del Convento de san Esteban de Salamanca, Salamanca, 1914, p. 488. Fenómenos similares se observan en el caso de otros conventos mendicantes en Castilla. Véase, Francisco José Rojo Alique, Op. Cit.

Hispania Sacra, LXI

124, julio-diciembre 2009, 483-512, ISSN: 0018-215-X 
Ahora bien, sería un error considerar a la Provincia dominica de España hacia 1460 como un depósito de frailes corruptos y, por ello, desinteresados de cualquier tipo de reforma. En efecto, hacia 1464 se reunió en Córdoba un capítulo provincial de fuerte carácter reformista ${ }^{11}$. Entre sus disposiciones se puede apreciar el modelo de fraile dominico que los conventos de la Provincia estaban acuñando - para nada alejado con el propuesto por las congregaciones de la reforma- en los que se remarcaba las exigencias respecto a la vida comunitaria, a una mayor observancia de la clausura monástica, a la dedicación al estudio y a la uniformación en el vestido y en la pobreza profesada.

Sin embargo, en 1467 se produjo un hecho de capital importancia para el proceso reformista. A instancias del cardenal Torquemada, el Maestro Auribelli visitó la Provincia de España y procedió a la creación de un vicario propio para la reforma, con poderes similares a los que tenían los superiores de la Congregación de la reforma de Lombardía. Para entonces, unos cuantos conventos habían sido ya reformados según el modelo de la reforma de San Pablo de Valladolid.

Entre 1474 y 1486, gracias al vigoroso apoyo que le prestaron los Reyes Católicos, la Congregación de la Reforma había aumentado sustancialmente el número de conventos sometidos a su jurisdicción en detrimento de la Provincia dominica de España. Sin embargo, hacia 1487 experimentó una delicada crisis. El celo reformista de sus vicarios, sobre todo de fray Alonso de San Cebrián, y la decidida oposición de las autoridades de la Provincia al tipo de reforma propiciada por la Congregación, convirtieron la vida de los conventos castellanos en una especie de combate. En ese contexto fue elegido para suceder a Vicente de Córdoba en la vicaría de la Congregación fray Pascual de Ampudia, fraile de San Pablo de Burgos, que había completado su formación en París y en Bolonia ${ }^{12}$.

Ampudia, que había colaborado en la fundación del Colegio de San Gregorio de Valladolid, fue destituido y restituido posteriormente de su cargo a lo largo de 1488. Durante el período que duró su destitución la Congregación quedó momentáneamente bajo la jurisdicción del provincial de España, que nombró un vicario suyo. Todo lleva a pensar que los frailes del poderoso convento de San Esteban, incorporado a la Congregación en 1486, formaban parte de esos manejos ante la Curia Generalicia. El carácter expeditivo del nuevo superior y la alarma que había incitado la fundación del colegio de San Gregorio de Valladolid, que minaba su influyente posición en el cuadro de la Provincia, habría conducido a los frailes salmantinos a pedir la destitución del vicario.

\footnotetext{
${ }^{11}$ Ramón HeRnÁNDEZ, «Acta del capítulo provincial de Córdoba de 1464», Archivo Dominicano, XV (1994), pp. 5-47.

12 Véase, Joaquín Ortega Martín, «Un reformador pretridentino: Don Pascual de Ampudia», Anthologica Аппиа, 19 (1972), pp. 257 y ss.
} 
Para plantar cara a esa oposición Ampudia reunió en 1489 el capítulo de la Congregación en el mismo convento de San Esteban. En esa reunión -la primera asamblea capitular de los reformados de la que se conservan sus Actas- se expuso la doctrina programática de la reforma dominica en términos disciplinarios y, al mismo tiempo, se dispuso la reorganización general de todas las comunidades, comenzando por el mismo convento de San Esteban de Salamanca, donde se desarrollaron las sesiones de esa asamblea ${ }^{13}$. Se trató de una reunión que por su obra legislativa señala un hito relevante en el proceso de identidad y de autoconciencia de la reforma religiosa entre los dominicos ${ }^{14}$.

En términos generales, la normativa emanada de las asambleas capitulares de la Congregación de la Reforma y, tras su disolución en 1504, de la Provincia, generarían la puesta en marcha de un proceso de caracterización social, que engendraría en las comunidades dominicas un modelo de vida regular más acorde a las necesidades de la sociedad castellana de la época que al pretendido modelo regular original de la Orden de Predicadores, tal como se habían propuesto los observantes en sus inicios ${ }^{15}$.

Durante la primera mitad del siglo XVI, época de elaboración de ese modelo de vida regular, la aceptación, el rechazo o la matización de las normas aprobadas por los reformadores se manifestó sobre todo a través de la producción literaria y la promoción interna de algunos frailes en desmedro de otros ${ }^{16}$. En efecto, la literatura emanada de los claustros dominicos, caracterizada por la composición de obras de teología moral, espiritual y dogmática, dedicada en

13 Expediente que se repetiría en cada una de las crisis que sufrió la Provincia. Por ejemplo en 1508, a raíz de la actuación del grupo de Piedrahita los capítulos de ese año y del año siguiente promovieron una redistribución de los miembros de todas las comunidades, algo similar sucedería en 15211522 con posterioridad a la guerra de las Comunidades.

${ }^{14}$ Dos capítulos habrían tenido lugar con anterioridad. De ellos no se conservan sus Actas, pero en el de Salamanca se dispondrá la observancia de la normativa aprobada allí. Véase, Ramón HERNÁNDEZ, «Actas de la Congregación de la Reforma de la provincia de España», Archivo Dominicano, I, 1980, pp. 7-70.

${ }^{15}$ Como en el caso general de muchas normas institucionales, las ordenaciones de la congregación pretendieron regular sobre todo conductas observables y en menor medida ideas y sentimientos, valga en este sentido la minuciosa regulación que experimentó la liturgia comunitaria y la casi inexistente ordenación que sufrió, al menos en este período, la oración individual. Una codificación exhaustiva del comportamiento hubiera constreñido más allá de lo deseable la conducta de los religiosos. Fueron reguladas, por lo tanto, aquellas conductas importantes o significativas para las comunidades, sobre todo las que se referían a la supervivencia, funcionamiento adecuado y productividad, así como al bienestar de los miembros.

16 Véase, Guillermo NiEva OCAMPO, «La creación de la observancia regular en el convento de San Esteban de Salamanca durante el reinado de los Reyes Católicos», Cuadernos de Historia de España, LXXX (2006), pp. 91-126.

Hispania Sacra, LXI

124, julio-diciembre 2009, 483-512, ISSN: 0018-215-X 
general a los mismos religiosos, remataría y completaría el proceso creativo iniciado por la generación de frailes legisladores de 1490, llenando de contenido la expresión observancia.

La definición y la práctica de los votos emitidos por los frailes reformados de la Orden de Santo Domingo son una buena muestra de algunos elementos caracterizantes de dicho modelo. Entre ellos, la pobreza fue escenario de conflictos y tema continuo de debates.

\section{LA POBREZA VOLUNTARIA Y EL DESPRENDIMIENTO DE LOS BIENES}

Ser un consagrado revestía una importancia capital a los ojos de los hombres y de las mujeres del siglo XV y XVI. Isabel la Católica no se cansa de remarcar en su correspondencia la importancia de los religiosos para sus reinos $\mathrm{y}$, por supuesto, la necesidad que éstos fueran observantes ${ }^{17}$. Por otra parte, todas las nuevas fundaciones religiosas y las vocaciones que florecieron en Castilla a lo largo de la época que tratamos son formas de vida comunitaria con votos ${ }^{18}$.

La oración cotidiana, la confesión periódica de los pecados y la comunión sacramental frecuente no fueron suficientes para satisfacer a los frailes reformados. Tampoco se trataba de elementos que los distinguiera particularmente del resto de los cristianos. Esenciales, los sacramentos necesitaban un medio adecuado para operar con plenitud la recepción de la gracia purificante que facultaba, a su vez, para contemplar la verdad. La práctica de las virtudes y la observancia de los votos hicieron de los frailes los depositarios de la plenitud de la gracia que, mediante su actividad apostólica, se derramaba sobre la humanidad. Estos dos últimos aspectos de la vida religiosa adquirieron en la época de la re-

${ }^{17}$ En una carta que la reina Isabel dirige al Maestro General Torriani, en 1496, destaca el valor que tiene la Orden de Predicadores y la observancia de sus miembros para el bien del reino: «Ya habéis sabido con cuanta diligencia, afición y voluntad entendemos en la buena reformación de los monesterios de nuestros reynos, porque el culto divino en nuestro tiempos será acrecentado y los religiosos con más limpieza de sus conciencias guarden sus regulares instituciones, que no an fecho fasta aquí. Y, porque entre las otras religiones que nos tenemos grande devoción, es la vuestra aquella [que] deseamos mucho ver reformada en verdadera observancia, por ende nos vos rogamos afectuosamente que por el servicio de Dios, honra y acrescentamiento de vuestra religión, queráys luego dar vuestro poder cumplido y bastante a fray Diego Magdaleno, de vuestra religión, conventual de Salamanca y vicario General de Santo Domingo de la Observancia en la Provincia de Castilla, para que pueda visitar y reformar todos los frayles y monesterios de vuestra Orden en la Provincia de Aragón ...», Archivo de la Corona de Aragón, reg. 3685, f. 120r.

18 Véase, E. MARTínez RuIz, El peso de la Iglesia. Cuatro siglos de Ordenes religiosas en España, Madrid, 2004, pp. 111-141. 
forma una centralidad que hasta entonces no había sido definida con tanta precisión por los dominicos de Castilla ${ }^{19}$.

Prometer ser obediente, pobre y casto el día de la profesión era un acto irrevocable y perpetuo: «Todo el carecimiento de deleites que se tienen por la castidad, todos los trabajos y aflicciones de la pobreza, todo el cansancio de las obras penosas que se hacen por la obediencia, si el religiosos quiere y se esfuerza, le convidan y le dan empellones que vaya a conversar con Dios para hallar en él santos placeres, verdaderas riquezas y seguro contentamiento», sentenciaba fray Pablo de León, fraile reformado del convento de San Esteban de Salamanca, en su Guía del Cielo, escrita hacia $1510^{20}$. La observancia ajustada de los votos permitía al religioso vencer el mundo y ganarse el paraíso.

Un monje reformado era ante todo un hombre que respetaba sus votos, incluso era capaz de aumentarlos con el fin de conquistar la humildad y de anularse. «La perfección del religioso consiste en la guarda de los tres votos substanciales de pobreza, obediencia y castidad», enseñaba fray Juan de la Cruz, fraile del convento de estricta observancia de Talavera, en su Dialogo sobre la necessidad y obligacion y prouecho de la oracion y diuinos loores vocales, obra escrita en $1555^{21}$. Según las órdenes, su número varía y al lado de las difíciles pobreza, obediencia y castidad, los reformadores solían agregar un voto de abstinencia de comer carne, para los hombres, o de estricta clausura para las mujeres.

Para los reformadores el voto de pobreza del fraile fue definido, ante todo, como un recurso liberador: «descuida al hombre y le quita la solicitud de los bienes temporales, que ahogan como zarzas la palabra de Dios y la memoria de sus misterios. Porque siendo como son las potencias de nuestra alma finitas, cuanto tiempo y con cuanta vehemencia se ocupan de las cosas terrenas, tanto se ajenan y despiden de las soberanas ${ }^{22}$. El religioso fue, por lo tanto, comparado con Abrahán, que había rechazado las riquezas que le ofrecía el rey de So-

${ }^{19}$ Claro está que desde finales del siglo XIII ya había quedado delineado el perfil vocacional del fraile dominico. En efecto, el Maestro General Humberto de Romans (1200-1277) con la elaboración de su célebre epístola De tribus votis, ofrecía a los frailes predicadores un cuadro general de los elementos que caracterizaban la propia vocación religiosa bajo unos rasgos eminentemente comunitarios. Con respecto al voto de pobreza había señalado, «qualiter sine proprio vivere debeatis doceamus. Igitur ex primitivae Ecclesiae perfectione discere poteritis quod habere cuncta communia debeatis. Act. 2. Creaturae idipsum vobis indicant in communicando bonum quod habent, et invicem sese donant; mutuo quoque sibi serviunt membra corporis, communitatem rerum per hoc indicantia vobis», H. de RoMANIS, Opera de vita regulari, ed. J. Berthier, vol. I, Roma, Marietti, p. 10.

${ }^{20}$ P. de León, Guía del Cielo, estudio preliminar y edición de Vicente Beltrán de Heredia, Barcelona, 1973, p. 488.

${ }_{21}$ Juan de la CRUZ, «Dialogo sobre la necesidad y obligación y provecho de la oración y divinos loores vocales», en Escritos espirituales, estudio preliminar y edición preparada por Vicente Beltrán de Heredia, Madrid, 1962, p. 438.

22 Juan de la Cruz, Op. cit, p. 486.

Hispania Sacra, LXI

124, julio-diciembre 2009, 483-512, ISSN: 0018-215-X 
doma como si dijera, «en sólo Dios tengo mi tesoro y por él desprecio todos los haberes del mundo», y también con David que dijo, «El Señor es la suerte de mi heredad y otra cosa que él no quiero en el cielo y en la tierra» (Ps. 71) 23.

La pobreza jamás fue desvalorizada por los reformadores, todo lo contrario, en virtud de la pobreza el fraile aligeraba su alma y se disponía mejor a la unión con Dios. «El alma que solamente codicia las riquezas de Dios y desprecia los tesoros que el mundo le puede dar (...) está facilitada y dispuesta para la oración y loores divinos» 24 . Se trata de un ideal y de un signo de elección, claro, a condición que sea aceptada, incluso deseada, buscada, adoptada y desposada, tal como lo había hecho Jesucristo:

«No cierto sin gran causa y misterio Nuestro Señor quiso ser pobre, y pobres quiso que convirtiesen el mundo; como si eligiera grandes reyes y él fuera poderoso, pues podía, más presto pudiera convertir el mundo y traerlo todo a sus conocimiento, y no quiso. Gran cosa y virtud debe estar en la pobreza voluntaria y prometida y votada por Dios. Creo que no alcanzamos a conocer ni a entenderlo; y por eso es poco amada y de los más aborrecida» 25 .

Si bien Cristo y sus apóstoles fueron el modelo del despojamiento del fraile observante, los reformadores hicieron lo posible para dejar en claro que ellos también estaban dispuestos a sufrir el peso de la ejemplaridad paternal. Fray Juan Hurtado de Mendoza (1478-1515), prototipo del fraile reformado -fundador de conventos y reiteradamente prior del convento de San Esteban de Salamanca- en muchos aspectos reunió esas condiciones al extremo del escándalo. En efecto:

«amaba mucho la santa pobreza y holgábase en extremo de verse en necesidad. Vióse en estos aprietos infinitas veces, contentísimo en las ocasiones que Dios le ofrecía así en las fundaciones de las nuevas casas como en las peregrinaciones y caminos forzosos que se le ofrecieron, en los cuales (...) su ordinario era ir pidiendo de puerta en puerta limosna por los caminos, huir del dinero y de la ocasión de tenerle, y dar de mano a todo lo que era honra y autoridad temporal. Y como quiera que de su natural era magnánimo y de corazón generoso, inclinado a magnificencia y liberalidad, no quería verse en tiempo de poder usar de su nobleza y condición, por no perder el mérito de la santa pobreza y humildad que en su estado profesaba» ${ }^{26}$.

${ }^{23}$ Ibíd., p. 487.

${ }^{24}$ Ibíd., p. 487.

${ }^{25}$ P. de LEÓN, Op. cit., p. 350. Un perfil biográfico actual sobre este fraile, que el padre Getino había identificado como comunero, en J. TABOADA, Historia del Convento de Nuestra Señora de Oviedo, edición de Lázaro Sastre Varas, Salamanca, 2002, pp. 208-213.

26 J. Cuervo, Op. cit, III, p. 561. 
En este sentido, la preocupación de los dominicos reformados por reglamentar, exigir y al fin suscitar un profundo amor entre los religiosos por la pobreza profesada, escondía además una mordaz crítica social. En efecto, el voto de pobreza religioso fue celebrado, ante todo, como medio de liberación de las ambiciones materiales que aprisionaban a los ricos, ya fueran estos laicos o eclesiásticos. « Oh pobreza voluntaria, que tiene vida segurísima, no teme ladrones, no hay pleitos, no temen tempestades! Lo cual temen los ricos, que nunca están sino con esta mudación de este templo y privanza de él y aumentar en este mundo y conservar aquel viento de la honra de él, que todo es estiércol», amonestaba fray Pablo de León ${ }^{27}$.

Sin embargo, la pobreza mendicante entre los frailes dominicos -tal como la había propuesto Santo Domingo- había suscitado una gran controversia en la Orden sobre la propiedad de los bienes, el propium, que los frailes del siglo XIII se afanaron por zanjar. La pobreza debía estar al servicio de los objetivos apostólicos de la Orden, el fraile a título personal debía ser escrupulosamente pobre, mientras que las comunidades tenían derecho a poseer legítimamente. La legislación y los hechos autorizaron la propiedad comunitaria, sobre todo a partir de la segunda mitad del siglo XIII ${ }^{28}$.

Santo Domingo habría propuesto a los primeros frailes las normas de la pobreza mendicante como condición de humildad exigida por la predicación según la forma evangélica y por lo tanto como forma privilegiada de la Sequela Christi, incluso en sus aspectos ascético-penitenciales. Sin embargo, con el tiempo, esas normas se revelaron no sólo radicalmente extrañas a la sensibilidad y a las costumbres de un grupo de clérigos intelectuales de extracción universitaria, sino objetivamente poco conciliables con las efectivas exigencias económicas vinculadas a la formación y al mantenimiento de un grupo de profesionales de la palabra escrita y de la predicación en la compleja realidad urbana del siglo XIII, sobre todo italiana ${ }^{29}$.

Ahora bien, en la época de la reforma aquella antigua discusión, reavivada por el mismo Raimundo de Capua, había resurgido en el seno de las comunidades dominicas ${ }^{30}$. De hecho, para los reformadores, la observancia -la vuelta al

${ }^{27}$ P. de LEÓN, Op. cit., p. 349.

28 Véase William A. HINNEBusch, «Poverty in the Order of Preachers», The Catholic Historical Review, XLV (1960), pp. 436-453; Marie-Hubert ViCAIRE, «Les origines de la pauvreté mendiante des Prêcheurs», Vie dominicaine, XXXIV (1975), pp. 195-206, 259-279; «Povertà, V, 1 (Predicatori)», Dizionario degli Istituti di Perfezione, VII, Roma, 1981, Col. 310-318.

29 Tesis sostenida por L. CANETTI, L'invenzione della memoria. Il culto e l'immagine di Domenico nella storia dei primi frati Predicatori, Spoleto, CISAM, 1997, pp. 397, 488-489.

${ }^{30}$ Sobre el pauperismo entre los franciscanos de la observancia y su influencia entre los religiosos de la época véase Melquíades ANDRÉs MARTín, «La espiritualidad franciscana en España en tiempos de las observancias (1380-1517)», Studia Storica, vol V (1987), pp. 465-479.

Hispania Sacra, LXI

124, julio-diciembre 2009, 483-512, ISSN: 0018-215-X 
antiguo espíritu de la Orden-incluía la estricta pobreza y la mendicidad ¿Cómo imitar a Cristo pobre si se vivía en comunidades ricas? La reforma recelaba en general de la riqueza y de la propiedad, es más, las consideraba obstáculos para la salvación. Todos estaban de acuerdo que a título personal ésta era válida e incluso obligatoria. Pero ¿hasta qué punto era lícito que los conventos fueran ricos? ¿La administración de los bienes no distraía a los frailes de sus obligaciones devocionales, apostólicas e intelectuales?

Sin embargo, la cuestación en la medida que las comunidades observantes comenzaron a aumentar producía poco y se tornaba difícil de realizar. El Papa Eugenio IV se encargó de devolver la calma a los frailes reformados al conceder al Maestro General de la Orden la facultad de dispensar a los conventos de la estricta pobreza, permitiéndoles poseer bienes y rentas ${ }^{31}$. Por su parte, para zanjar definitivamente la cuestión, el 1 de julio de 1475, otro pontífice, Sixto IV -antiguo Fraile Menor y Ministro General de su Orden, y, por lo tanto, conocedor profundo de la situación práctica de las órdenes mendicantes- otorgó al maestro general Leonardo de Mansuetis la bula por la que concedía a los conventos dominicos el derecho a la propiedad absoluta de sus bienes ${ }^{32}$. Los frailes podían seguir mendigando, pero también acumular y asegurarse la existencia para el futuro. Finalmente, la legislación se completó en 1489 cuando Inocencio VIII anuló un texto sobre la pobreza de gran encanto para los dominicos de la Congregación de la reforma. Se trata del denominado testamento de Santo Domingo ${ }^{33}$. Con ello se libraba a los frailes de las condenas del fundador sobre la propiedad de bienes, se beneficiaba a las comunidades que se encontraban en vías de un desarrollo económico mayor gracias a la coyuntura favorable y, obviamente, se perjudicaba a aquellos reformadores que pretendían aún extender la práctica de la pobreza al ámbito comunitario.

Por otro lado, el ingreso de numerosos individuos a la vida consagrada a partir de la década de 1470 -a medida que avanzaba la reforma- se había traducido en un aumento considerable del capital inmobiliario y monetario de los conventos, gracias a los bienes incorporados por esos nuevos frailes ${ }^{34}$. De allí que los conventos mayores de la Orden en Castilla, como San Esteban de Sala-

31 Una síntesis completa de la controversia en torno a la propiedad se puede consultar en A. MorTIER, Histoire de Maîtres Généraux de l'Ordre des Frères Prêcheurs (1400-1486), vol. IV, Paris, 1909 , pp. 493 y ss.

${ }^{32}$ Bullarium Ordinis Fratrum Praedicatorum, III, p. 528.

33 Véase, Raymond CREYTENS, «Le 'testament de S. Dominique' dans la littérature dominicaine ancienne et moderne», Archivum Fratrum Praedicatorum, 43 (1973), pp. 23-72.

${ }^{34}$ Sirva de ejemplo el caso del convento de San Esteban de Salamanca que pasó de 20 frailes hacia 1450 a más de 150 a mediados del siglo XVI. Véase nuestro artículo, «La creación de la observancia regular en el convento de San Esteban de Salamanca durante el reinado de los Reyes Católicos», Cuadernos de historia de España, 80 (2006), pp. 91-126. 
manca, San Pablo de Valladolid o San Pablo de Burgos, experimentaron un notable acrecentamiento de su patrimonio, viéndose obligados a protegerlo $\mathrm{y}$, al mismo tiempo, a ampliarlo, al amparo de una coyuntura favorable.

Los reformadores se encargaron ante todo que el uso de esos bienes comunitarios quedara bien regulado. Registrar las escrituras de todos los bienes que cada convento poseía, comunicar la situación económica de las comunidades a los superiores provinciales, moderarse en las expensas, no realizar construcciones sin previa autorización de las autoridades provinciales, poner en común todos los bienes que a título personal se recibieran y no aceptar dinero en depósito, fueron las medidas reiteradas continuamente por las autoridades provinciales ${ }^{35}$. Los padres también se encargaron de incrementar la supervisión del dinero comunitario ordenando que fueran tres los depositarios «teniendo tres llaves diferentes, y que nunca entre uno solo en el depósito para escribir las cosas dadas y recibidas, y que en el lugar del que falte esté presente uno de los frailes antiguos del convento, y deje el libro fuera del arca del depósito» ${ }^{36}$.

Sin embargo, un buen número de religiosos, partidarios de una estricta observancia, no vieron con buenos ojos la política acumulativa, sobre todo de los grandes conventos. Esos frailes, apoyados en poderosos eclesiásticos y laicos del reino (cardenal Cisneros, la reina y algunos nobles) así como en el poder efectivo que tenían entre los frailes de la Congregación de la Reforma -al menos hasta la visita del maestro de la Orden, Vicente Bandelli, en 1504, que coincide con la muerte de la reina Isabel- intentaron la creación de una congregación aparte, a imitación de la Congregación de San Marcos, siguiendo el ejemplo del italiano Jerónimo Savonarola ${ }^{37}$. Si bien el plan fue fallido por la intervención del Maestro General, Tomás de Vio Cayetano, que ordenó el aislamiento de la Beata de Piedrahita y la separación y dispersión de sus seguidores, el pauperismo no quedó exterminado.

El pauperismo comunitario entre los frailes dominicos sobrevivió y se manifestó, entre otros, en las fundaciones de comunidades observantes realizadas por fray Juan Hurtado en Castilla, en la actividad apostólica de fray Pablo de León en Asturias y entre los primeros misioneros en Indias ${ }^{38}$. Hay que recono-

\footnotetext{
${ }^{35}$ Ramón HeRnÁndeZ, «Actas de la Congregación de la reforma», Archivo Dominicano, I (1981), p. 54, 55; Ibidem, II (1982), p. 59, 93-94.

${ }^{36}$ Ramón HeRnÁNDEZ, «Acta del capítulo provincial de Toledo de 1518», A. D., XVI (1995), p. 17.

37 Véase, J. Benavent, Savonarola y España, pp. 31-34, 116-119. La relación entre Bandelli y Savonarola ha sido estudiada por Michael TAvUZZI, «Savonarola and Vicenzio Bandello», Archivum Fratrum Praedicatorum, 69 (1999), pp. 199-224.

${ }^{38}$ Ambas experiencias sirvieron, junto con la empresa americana, para drenar hacia en empresas misionales a todos aquellos religiosos que simpatizaban con las fatigas de la vida de pobreza, con los riegos de la predicación misionera e incluso con el martirio. Por otro lado, la ansiedad producida por una espiritualidad extremadamente ascética encontraba de este modo una posibilidad de alivio. Hemos
}

Hispania Sacra, LXI

124, julio-diciembre 2009, 483-512, ISSN: 0018-215-X 
cer que las motivaciones que animaron a los dos primeros a dar nacimiento a comunidades de estricta pobreza eran ciertamente diferentes, pero respondían a parámetros similares. Fray Juan Hurtado, disconforme con la holganza económica que reinaba en el convento de San Esteban de Salamanca hacia 1518, deseaba la fundación de comunidades mendicantes y pobres, tal el caso de los conventos de Ocaña, Talavera y Atocha, y se deleitó mientras la pobreza del período fundacional de esos tres cenobios duró ${ }^{39}$.

En cambio, desde una posición más conservadora, fray Pablo de León negoció durante años el patrocinio de la fundación del convento de Oviedo para poder comenzarlo en un sitio adecuado y con renta abundante. De hecho no tuvo reparos en recibir las ayudas necesarias, si bien los frailes aceptaron la vida de extrema pobreza de la comunidad en sus inicios con un fuerte sentido de ejemplaridad apostólica ${ }^{40}$. Inicios más bien dilatados, los del convento de Oviedo, que se tradujeron en un reclutamiento flaco durante casi todo el siglo XVI ${ }^{41}$.

Por su parte, los que llegaron a la isla de Santo Domingo en septiembre de 1510 , castellanos todos, habían encontrado la ayuda de un vecino de la ciudad llamado Pedro Lumbreras. Los frailes, acostumbrados a las estrecheces inculcadas por los maestros de la observancia, aceptaron gustosos la choza en las que fueron alojados y se adaptaron rápidamente a la magra dieta de los isleños más pobres: aprendieron a gustar el cazabe -pan de mandioca-, comían huevos y algún pescado que conseguían de vez en cuando. "Alguna cocina de berzas, muchas veces sin aceite, solamente con axí que es la pimienta de los indios». Por si fuera poco «ayunaban siete meses del año arreo, según de si Orden lo tenían y lo tienen mandado», desde el 14 de septiembre hasta Pascua, añadiendo «ciertas ordenaciones y reglas sobre las viejas constituciones de la Orden (que no hace poco quien las guarda) para vivir con más rigor. Por manera que ocupados en guardar las nuevas añadidas reglas, estuviesen ciertos que las constituciones antiguas [...] estaban inviolablemente en su fuerza $\mathrm{y}$ vigor» ${ }^{42}$.

tratado ya ese fenómeno en Guillermo NIEVA OCAMPO, «La reforma del convento de San Esteban de Salamanca y el modelo comunitario triunfante en el siglo XVI», en Segundas jornadas de Historia de la Orden Dominicana en la Argentina, Actas, Agosto de 2005, San Miguel de Tucumán, 2005, pp. 265-280.

39 J. Cuervo, Op. cit., III, pp. 536-540.

40 J. TABoAda, Historia del Convento de Nuestra Señora del Rosario de Oviedo, edición a cargo de Lázaro Sastre Varas, Salamanca, 2002, pp. 220-224.

${ }^{41}$ En la introducción a la crónica de fray Juan Taboada, el padre Lázaro Sastre ofrece un estudio demográfico del convento, según el libro de profesiones del convento ovetense, que incluye un análisis comparativo con otros conventos dominicos de diversa entidad. J. TABOADA, Op. cit., 2002, pp.109143.

42 B. de Las Casas, Historia de las Indias, II, edición, prólogo, notas y cronología: André SaintLu, Madrid, 1957, p. 133. 
Esa forma de vida sería fundamental para la actuación evangelizadora de los primeros dominicos en Indias. La pobreza debía hacerlos aptos para la máxima disponibilidad, a la vez que les presentaba totalmente desinteresados ante los españoles y naturales. Su predicación sería totalmente libre, sin supeditación a personas o instituciones que pudieran hacer acallar sus palabras. Para que la libertad fuera completa, decidieron en común no pedir limosna, «pero si sin pedillo se lo enviasen, que lo comiesen haciendo gracias a Dios». Gracias a ese modo de vida durante muchos días se quedaron sin comer. Sin embargo, su palabra terminó siendo espada afilada en medio de aquella sociedad que les terminó negando el mínimo sustento, porque al predicar contra las encomiendas y mercado de esclavos, tal como apuntara Bartolomé de las Casas, «quitaban la hacienda» a los señores de la tierra ${ }^{43}$.

\section{LA POBREZA VOLUNTARIA Y EL CONFORT COMUNITARIO}

No obstante, los más importantes conventos dominicos de Castilla, poblados sobre todo por clérigos intelectuales o por predicadores instruidos, resistieron la conversión hacia las formas de pobreza mendicante. Como sea, la legislación de la reforma, que no se propuso jamás atacar seriamente la propiedad común de los bienes entre los dominicos, terminó por acompañar el pensamiento de estas comunidades. De hecho, los superiores de la Orden hicieron lo posible para que los bienes de los conventos fueran preservados e incluso acrecentados. Frente a los litigios que se habían suscitado con las familias de los frailes, el capítulo provincial de Toro de 1516 suspendió la revocación de la legítima, que habían ordenado anteriormente los reformadores, porque «parece irracional obrar en contra de lo ya establecido por el convento en bien de la paz, y es escandaloso para los seglares» ${ }^{44}$. En consecuencia, se autorizaba la recepción de todas las herencias de los frailes y se conminaba la aceptación de los convenios que estos habían realizado para su obtención.

La pobreza voluntaria de los frailes reformados no fue nunca considerada como una reducción a la precariedad del mañana, tal como lo habían experimentado numerosas comunidades a principios del siglo XV. Los observantes se descargaron de preocupaciones materiales en razón del retorno de la prosperidad. La pobreza voluntaria impuso el olvido de las preocupaciones de los bienes de este mundo mientras estaba asegurada su provisión. Esos religiosos entendían que buscar lo necesario para vivir era pecado, mientras que, inversamente, estaba asegurada la salvación de aquel que vivía voluntariamente

${ }^{43}$ Ibidem.

${ }^{44}$ Ramón HeRnÁNDEZ, «Actas del capítulo provincial de Toro de 1516», A. D., XIV (1993), p. 27.

Hispania Sacra, LXI

124, julio-diciembre 2009, 483-512, ISSN: 0018-215-X 
e individualmente pobre en un cuadro decente y opulento, aliviado de preocupaciones temporales y sin miedo a la precariedad. Para lo reformadores pobreza individual no rimaba con pobreza colectiva e inconfort. Los testimonios sobreabundan desde los comienzos de la reforma y se imponen a lo largo de su trayecto ${ }^{45}$.

Un ejemplo elocuente lo constituye el Convento de San Pablo de Valladolid, casa madre de la reforma en Castilla. Como lo había hecho anteriormente en el Convento de Santa María Sopraminerva, el cardenal Torquemada había comenzado la reforma de San Pablo de Valladolid por la fábrica del convento. La suntuosa reconstrucción de la iglesia y del convento, iniciada en 1452, debía manifestar, por una parte, el fin sublime de la disciplina monástica, la gloria divina, y por otra, el fin de la Orden dominica, el estudio como instancia preparatoria del fraile predicador. Como los fondos del cardenal no alcanzaron para cubrir los costos elevados del portal plateresco de San Pablo, el prelado obtuvo indulgencias del Papa con cuyas aportaciones se pudieron completar las obras hacia $1463^{46}$.

Torquemada, ya anciano, estaba muy interesado en la reforma del convento donde él mismo había profesado. En efecto, el cardenal estaba convencido que su hora para compadecer ante el Juez Eterno se acercaba. De hecho, el siete de agosto de 1460 había recibido autorización del Papa para redactar testamento y última voluntad ${ }^{47}$. De allí que resulte lógico su comedimiento por refaccionar la fabrica de un convento e iglesia que deseaba quizás como última morada y que, a su vez, estuviera sumamente interesado por la religiosidad de los frailes, cuya

45 Este pensamiento hizo escuela entre los dominicos. De hecho, promediando el siglo, en ese mismo sentido aconsejaba Domingo Báñez a Teresa de Jesús acerca del sostenimiento económico de sus fundaciones. De hecho, la santa abulense, empeñada en fundar «monasterios de limosna» se topó continuamente con el reproche del fraile dominico que la aconsejaba de fundar monasterios con renta. Véase, José Antonio Álvarez VÁzQuEZ, «Teresa de Jesús y la Escuela de Salamanca», Cuadernos de Ciencias Económicas y Empresariales, ${ }^{\circ} 37$ (2000), pp. 121-128. Un desarrollo más extenso de su tesis en el libro Trabajos, dineros y negocios: Teresa de Jesús y la economía del siglo XVI (1562-1582), Madrid, Trotta, 2000.

46 Los documentos sobre la participación del cardenal en la reparación de la iglesia y convento de San Pablo han sido publicados en Vicente BELTRÁN DE HEREDIA, «Colección de documentos inéditos para ilustrar la vida del cardenal Juan de Torquemada», Archivum Fratrum Praedicatorum, VII (1937), pp. 210-245.

47 Registro Vaticano 503, fol. 168r-v, ha sido publicado por Vicente BELTRÁN DE HEREDIA, «Noticias y documentos para la biografía del cardenal Juan de Torquemada», Archivum Fratrum Praedicatorum, XXX (1960), p. 131. La colaboración entre el cardenal Torquemada y Pio II se centró desde el comienzo del pontificado en la puesta en marcha de una cruzada contra los turcos, donde al prelado español desarrolló sendas tareas diplomáticas. A partir de entonces Torquemada se convirtió en uno de los cardenales del consejo de Eneas Silvio Piccolomini. Véase, T. M. IzBICKI, Protector of the faith: Cardinal Johannes de Turrecremata and the defense of the institutional Church, Washington, 1981, pp. 22-27. 
estricta observancia regular garantizaba la eficacia de las plegarias elevadas por vivos y por muertos ${ }^{48}$. Hasta entonces, los frailes de San Pablo, según Torquemada, habían cumplido con una observancia de la vida regular que les era insuficiente para alcanzar la propia salvación y para garantizar la de los demás. ¿No era acaso la pobreza económica del cenobio un signo de la ausencia de la ayuda divina cuando el mismo Cristo había prometido el «céntuplo» a los que renunciaban a los propios bienes para seguirle? De allí que fuera necesario subsanar el mal dotando a los frailes de un ámbito adecuado a su labor intercesora y de reformar sus costumbres ${ }^{49}$. Así también volverían a gozar del favor divino y, como no, de las donaciones de los poderosos.

En Valladolid, la obra arquitectónica fue continuada por fray Alonso de Burgos, obispo de Palencia, que costeó la parte baja de la fachada, las portadas del crucero, su capilla funeraria y el anejo Colegio de San Gregorio. Fray Alonso se construyó una capilla privada para su enterramiento, para lo cual pidió a los religiosos la capilla del Crucifijo. Esta obra fue encargada a Juan Guas, quien estuvo como maestro, y Juan de Talavera como su ayudante. Las obras se llevaron a cabo entre 1484 y 1490, en plena época reformista. Para compensar mandó construir una capilla para el Crucifijo en el lado frontero del transepto. La portada de acceso de la capilla funeraria debió realizarse en torno a 1490; parece ser que en ella intervino Guas, pero las figuras son más próximas a Gil de Siloé, que ya había terminado el retablo de la iglesia; por lo que su construcción se podría centrar entre 1488 y 1492, fecha de la erección de San Gregorio. A mediados del siglo XVI se renueva el cuerpo de la iglesia y se decide abovedarlo y elevarlo, para lo que fue necesario introducir un cuerpo más en la fachada, levantando el frontón para introducir el cuerpo intermedio. El obispo palentino contrató a Simón de Colonia para la realización de la fachada. La portada es una exaltación gloriosa de la Orden dominica. En las jambas aparecen santas dominicas: Santa Margarita, Santa María Magdalena, Santa Catalina de Alejandría y Santa Catalina de Siena. En las arquivoltas aparecen santos dominicos. En los laterales hay cuatro santos: San Pedro mártir, Santo Domingo de Guz-

\footnotetext{
48 Sobre la mediación religiosa de los frailes véase, Guillermo NieVA OCAMPO, «En la iglesia con alta y sonora voz: liturgia y oración entre los dominicos reformados de Castilla (1480-1550)», Pecia, 16 (2008).

${ }^{49}$ Así se lo hizo saber a fray Juan de Gumiel, prior del monasterio benedictino de San Benito de Valladolid: «Cuanto más nos encarga la vejedad y se apropicua el tiempo de la nuestra resolución, tanto más nos cresce el deseo que el convento de San Pablo, donde Nos recibimos el hábito de religión, fuese reformado en tal observancia, sin la cual non es esperanza de salvación a religiosos». Carta del cardenal fray Juan de Torquemada al prior de San Benito de Valladolid. Roma 5 de marzo de 1461, Archivo Histórico Nacional (AHN), Clero: Valladolid, leg. 449, documento publicado por Vicente BELTRÁN DE HEREDIA, «Colección de documentos inéditos para ilustrar la vida del cardenal Juan de Torquemada O.P.», Archivum Fratrum Praedicatorum, 7 (1937), p. 230.
}

Hispania Sacra, LXI

124, julio-diciembre 2009, 483-512, ISSN: 0018-215-X 
mán, Santo Tomás de Aquino y San Vicente Ferrer. En la arquivolta del arco exterior hay otros santos innominados. En el tímpano, sobre el dintel, aparece la Coronación de la Virgen entre coros de ángeles músicos, acompañada de los dos santos Juanes y del obispo fray Alonso de Burgos. Flanqueándolo todo se presentan los escudos del promotor. Esta Coronación fue ejecutada según un modelo muy seguido en Alemania a finales del siglo XV: la Coronación por la Santísima Trinidad 50 .

Otro ejemplo también relevante lo brinda la historia material del Convento de San Esteban de Salamanca. Allí ni siquiera el austero fray Juan Hurtado durante su doble priorato (de 1518 a 1519 el primero y de 1521 a 1524 el segundo) pretendió deshacerse de un palmo de propiedad de ese poderoso cenobio. Es más, todos los priores que gobernaron en época de la reforma, así como el capítulo del convento salmantino, aceptaron sin grandes reparos los bienes que les distribuía la providencia divina, defendieron con fiereza su patrimonio de la codicia de otros poderosos y, coincidiendo con los comienzos de la implantación de la observancia, ampliaron y embellecieron el recinto de su convento.

De ese modo, el cuadro material del San Esteban de Salamanca se adaptó al aumento de las profesiones que experimentó desde las últimas décadas del siglo $\mathrm{XV}$, en particular desde su incorporación a la Congregación de la reforma en $1486^{51}$. En 1492 la comunidad de San Esteban recibió de los Reyes Católicos el predio adyacente al convento, denominado Monte Olivete, dotándose de un espacio idóneo para la ampliación de sus edificios. En los años sucesivos irán ampliado esa propiedad mediante una serie de compras y allí se localizará, tras su fundación, el Colegio Menor del Monte Olivete ${ }^{52}$. Asimismo, la lista de trabajos efectuados en el convento permite constatar que durante la década

\footnotetext{
${ }^{50}$ R. Vivar CANTero, Guía de Arquitectura Urbana de Valladolid, Valladolid, 2006.

${ }^{51}$ El crecimiento demográfico del convento de San Esteban (de 20 frailes hacia 1450 a más de 200 hacia 1550) se pueden estudiar en mi trabajo «La creación de la observancia regular en el convento de San Esteban de Salamanca durante el reinado de los Reyes Católicos», Cuadernos de Historia de España, 80 (2006), pp. 93-128.

52 J. CUERVO, Op. cit., III, p. 502. En los documentos notariales que se encuentran en el Archivo Histórico Nacional se puede seguir con lujo de detalle la política patrimonial del convento respecto a este predio. La primera compra se realizó en 1490 y a continuación se solicitó la intervención de los Reyes porque el convento tenía problemas con los vecinos de la zona, en concreto con aquellos peleteros que realizaban allí tareas de curtiembre. Los litigios no terminaron hasta la tercera década del siglo XVI, ya que el convento continuó ampliando sus propiedades en la zona mediante una política sistemática de compras y porque finalmente inició la construcción del edificio del Colegio, topándose en 1524 con la resistencia del mismo Ayuntamiento. En el antiguo catálogo del archivo conventual los documentos relacionados con el Monte Olivete estaban ubicados en el cajón 15, actualmente se encuentran en A.H.N., Clero, legs. 5911 y 5938. Una copia de la merced otorgada por los Reyes Católicos en 1492 también se encuentra en Archivo General de Simancas, Sello, VII, 4168, fol. 115.
} 
de 1490 la comunidad se comenzó a dotar de nuevos y más amplios recintos. Entre ellos podemos mencionar la ampliación de su refectorio hacia 1493, que fue costeado por el Maestre de la Orden de Santiago D. Rodrigo Manrique, y la construcción de una nueva enfermería, que mandó edificar el obispo Fonseca ${ }^{53}$. Todavía en 1504 la reina Isabel ordenaba que se enviase como limosna al prior de San Esteban de Salamanca 50.000 maravedíes para las obras del convento, que se debía descontar «de lo procedido de la Cámara de Sicilia» 54 .

La dimensión numérica de la comunidad así como los trabajos que se realizaron manifiesta el reflorecimiento de la pasión por la vida monástica reformada a lo largo del siglo XVI. La población conventual llegaría a ser tan grande, respecto al recinto que la cobijaba, que cuando se ordenó la incorporación al convento de los frailes dominicos residentes en la ciudad de Salamanca por estudio -asunto que resultó inevitable para ellos tras la unión de la Provincia con la Congregación en 1504- se tuvo que disponer la ejecución de nuevas obras para la ampliación del recinto y se decidió que esos nuevos residentes vivieran en alojamientos particulares. De esta época datan también los trabajos en la finca de Valcuevo, más o menos a dos leguas de Salamanca, que se amplió y acondicionó para cobijar una parte de la comunidad que allí residía durante el receso escolar, convirtiéndose en residencia de descanso de los frailes.

Las obras de ampliación y decoración del convento continuaron a lo largo de todo el siglo XVI y buena parte del XVII en virtud del incesante crecimiento de la comunidad y, sobre todo, por el deseo de sus bienhechores y de los mismos frailes de embellecer la fabrica del cenobio y la iglesia ${ }^{55}$. Para sufragar todas esas inversiones los administradores conventuales utilizaron los recursos devenidos de la administración de sus numerosos bienes, que a lo largo del siglo se habían acrecentado enormemente. Los dominicos de Salamanca contaban para la época con cuatro cotos redondos -que incluían molinos, pesquerías y viñedos- situados en la cuenca del Tormes, así como casas que alquilaban en la ciudad de Salamanca. Además habían incorporado importantes propiedades en Extemadura y en las cercanías de Medina del Campo, esta última, la Naba del Rey, proporcionaba buenos pastos a la numerosa cabaña ovina de los frailes. El expediente patrimonial se completó a lo largo del siglo XVI con juros y censos en distintas ciudades del reino. Fray Nicolás de Santo Tomás, que fue subprior del convento hacia 1527, a tres años del comienzo de las obras de reforma del templo, dejó el siguiente testimonio: «si la claustra del dicho monasterio se

\footnotetext{
53 J. CuERVo, Op. cit., III, p. 504.

${ }^{54}$ Archivo General de Simancas, Casa real, obras y bosques, leg. 4, fol. 274.

55 Un estudio detallado de la historia material de la iglesia y del convento de San Esteban de Salamanca en A. Rodríguez G. De Ceballos, La Iglesia y el convento de San Esteban de Salamanca, Salamanca, 1987, pp. 13-120.
}

Hispania Sacra, LXI

124, julio-diciembre 2009, 483-512, ISSN: 0018-215-X 
hizo, sabe que se bendyó una posesión que el dicho monasterio tenía por cinco myll ducados poco más o menos y si en la dicha claustra se pusieron las armas del dicho Cardenal (Juan Álvarez de Toledo) no fue por hazer él la obra ny mandarlo él, syno porque el dicho conbento le quiso hazer aquella gracia por tenelle más contento» ${ }^{56}$.

Con respecto al convento de Santo Tomás de Ávila sus orígenes estuvieron vinculados al favor de los Reyes Católicos ${ }^{57}$. Este cenobio fue fundado en 1481 a instancias del tesorero de la reina Isabel, Hernán Nuñez de Arnalte, quien dotó a la fundación con millón y medio de maravedíes para su construcción. Tras su muerte en 1482 la obra sería continuada por fray Tomás de Torquemada -confesor de la reina e inquisidor general- y doña María Dávila que recibieron sendas ayudas económicas de los monarcas, sobre todo para la construcción de la iglesia -que pasó a albergar lo restos del infante don Juan-y de los claustros del silencio y de los Reyes, el claustro del noviciado había sido terminado en la primera fase.

El convento, con sus tres claustros y su monumental iglesia fue realizado para los frailes de la reforma, es más, su construcción principal quedó completada antes de la disolución de la Congregación, ocurrida en 150458. Por lo tanto, resulta un claro ejemplo del concepto de desahogo y magnificencia comunitaria que los dominicos reformados dieron a sus residencias.

${ }^{56}$ A. H. N., Clero, leg. 5927, Pleito de 1560, «Probanza del Convento de San Esteban», fol. 69

57 Sobre el convento de Santo Tomás de Ávila véase el reciente estudio de Beatriz I. CAMPDERÁ GutiérReZ, «Arte y Arquitectura en Santo Tomás de Ávila», en F. J. CAMPOS y FernándeZ de SEvilla, Monjes y monasterios españoles: actas del simposium, Vol. 1, El Escorial, 1995; Santo Tomás de Ávila: historia de un proceso crono-constructivo, Ávila, 2006.

${ }^{58} \mathrm{El}$ claustro del noviciado es de estilo toscano. Tiene dos pisos desiguales, en granito, de 20 arcos y veinte columnas cada uno. Abajo, tiene arcos de medio punto, arrancando de columnas sin basamento y de forma octogonal, mientras que en el piso superior, los arcos son escarzados de amplias circunferencias. Por su parte el claustro del silencio o de los difuntos, porque allí eran enterrados los frailes, tiene unas medidas de 19,40 por 20,90 metros y se compone de dos plantas. Consta de 18 arcos, con dos puertas de acceso en su parte inferior, y de 38 arcos polilobulados en su parte superior. Destaca abajo la bóveda de crucería de estilo gótico. Los muros del interior permiten contemplar un total de siete puertas que comunican con distintas dependencias, todas ellas con arcos estructuras y diferentes. El claustro cuenta también con un rincón recoleto donde los religiosos se lavaban las manos antes de pasar al refectorio. El claustro de los Reyes estaba destinado a Palacio de verano de los monarcas. Con sus 35 metros por 37,5 es muy amplio y luminoso. Lo forman cuarenta arcos en su parte inferior y 56 en la superior. Finalmente, la iglesia en forma de cruz latina tiene unas medidas de 53 metros de largo por 10,50 de ancho y el crucero mide 28,80 metros de largo por 10,30 de ancho. Es una joya de la arquitectura flamígera. El crucero, delimitado por cuatro columnas, semejando ramas de palmera, forma un joyero para el sepulcro del príncipe Juan. La obra más importante que contiene esta iglesia es el retablo mayor, realizado por Berruguete (1440-1504) que exalta los valores más apreciados por los dominicos de la reforma: la piedad, la observancia, la lucha contra los herejes, etc. 


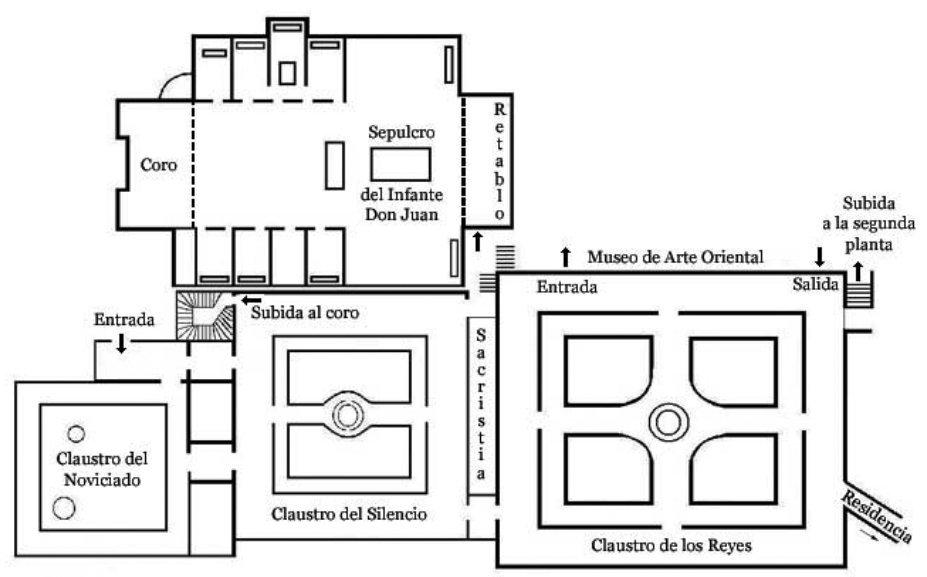

Planta del Real Monasterio de Santo Tomás de Ávila

El embellecimiento y la ampliación del recinto de los conventos, en una época que pregonaba la estricta pobreza individual del fraile, fue deudor de una valoración sagrada otorgada al edificio por los mismos religiosos:

«convenientísmo para la oración y provocan a ella a sus moradores: donde no hay recámaras de arreos y vestidos que conviden a vanidades; donde no hay salas de armas que enciendan a ira y contenciones; donde no hay bancos de cambiadores ni tiendas de mercaderes que provoquen codicia de terrenas ganancias, más todos están llenos de aparejos e instrumentos para ejercicios espirituales» ${ }^{59}$.

Los costosos y cuidados arreglos y mejoras a la fábrica conventual, así como la regulación de sus espacios eran el fruto de una representación simbólica que hacía del convento aquí abajo el lugar ideal para entrever la visión beatífica ${ }^{60}$. Y es que el fraile no debía ser distraído de ese oficio, ni inducido a ningún tipo de extravío ya que en los conventos, «por otros ejercicios (los religiosos) se hacen compañeros y muy afines a la oración, como es la frecuente lección de la Escritura sagrada y de santos doctores, las pláticas y amonestaciones a buenas costumbres, así de los prelados a los súbditos como de los hermanos entre sí» ${ }^{61}$.

\footnotetext{
59 Juan de la CRUZ, Op. cit., p. 497.

${ }^{60}$ Representación que la cultura barroca se encargará de ampliar y profundizar, aplicándola a toda la arquitectura religiosa. Sobre este tema véase, Elías Hernández AlBALAdEJo, «Nobilis, Pulcra, Dives. La catedral como espacio sagrado», en Huellas. Catálogo de la Exposición. Catedral de Murcia, Murcia, 2002, pp. 88-108.

61 Juan de la CRUZ, Op. cit., p. 498.
}

Hispania Sacra, LXI

124, julio-diciembre 2009, 483-512, ISSN: 0018-215-X 
Por otra parte, ¿no había sido el Maestro Angélico quien identificara lo bueno y perfecto con lo bello y deseable?62.

De este modo, los reformadores estuvieron en realidad mucho más preocupados por el uso de los bienes que por su posesión, que en último término consideraban necesaria para el mantenimiento de la comunidad y la subsistencia de los frailes ${ }^{63}$. En 1518 el maestro general Tomás de Vio Cayetano (1469-1534), a raíz de las disposiciones del Concilio de Letrán V, informaba a los frailes de la Provincia de España que los privilegios y exenciones que gozaban los conventos castellanos no habían sido mermados ni enajenados y recomendaba que se hiciera un uso «de ellos circunspecta y religiosamente, de tal manera que por ningún motivo quebrantéis el tenor de los mismos y merezcáis perderlos, abusando de la potestad concedida» ${ }^{64}$.

Por todo ello, la observancia hizo un esfuerzo ingente por asegurarse que el fraile fuera consciente que el voto de pobreza lo convertía a título personal en un pobre. Sólo, habiendo renunciado al mundo, a sus amigos y a su familia, por deseo de pobreza, el fraile únicamente podía contar para su sustento con sus hermanos de religión, su nueva familia. De allí la preocupación de los reformadores por reconstruir la enfermería y por aumentar los cuidados a los enfermos. En consecuencia, la caridad ante todo debía estar dirigida a la fraternidad monástica: «Admoneo omnes Praelatos et officiales ut provideant fratribus honestes in suis necesitatibus, ita quod non detur ocasio fratribus procurandi sibi quaerendi quae sua sunt», había exhortado fray Vicente Bandelli a los priores castellanos en 150465 . El prójimo al que se debía ayudar era un próximo, por-

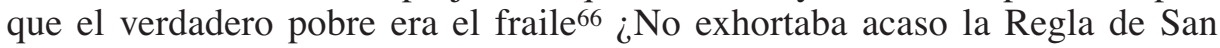

\footnotetext{
62 Summa Theologiae, I, q. 5, a. 4 ad 1; Ia-IIae, q 27 a. 1 ad 3; IIa-IIae, q. 168 a. 4. Expositio in Dionysium de divinis nominibus, 367 b, 398. En el alba de la Edad Moderna la reforma se encargó de rehabilitar a Santo Tomás y de convertir su pensamiento en dominante. Un estudio general sobre la estética medieval y el valor del pulchrum como atributo de lo divino en J. JACQUES PI, La estética del románico y el gótico, Madrid, 2003.

${ }^{63}$ Concepción estrechamente vinculada a la principal preocupación de la reforma: la perfección individual como medio de reforma eclesial. Véase, Melquíades ANDRÉS MARTín, «Pensamiento teológico y vivencia religiosa en la reforma española (1400-1600)» en J. L. GonZÁLEZ Novalin, Historia de la Iglesia en España, III-2 ${ }^{\circ}$, Madrid, 1980, pp. 330.

${ }^{64} \mathrm{R}$. HeRNÁNDEZ, «Actas del capítulo provincial de Salamanca de 1518», A. D., XVIII, (1997), p. 19.

${ }^{65}$ R. HeRnándeZ, «Actas de la Congregación de la reforma», A. D., II, p. 93. Tal como había sido concebido en la Edad Media, la pobreza voluntaria hacía de los monjes los herederos de los primeros cristianos, no tanto por rechazar la posesión de los bienes, sino por compartirlos en la propia comunidad. Véase, E. Mitre Fernández, Fronterizos de Clío (Marginados, disidentes y desplazados en la Edad Media), Granada, 2003, pp. 36-41.

${ }^{66}$ Los canonistas de la Orden llegarían a admitir, como norma canónica, que «más fácilmente se puede llegar a pecado mortal dando a los extraños que a los de la comunidad», P. LÁrRAGA - F. de LuMBRERAS, Prontuario de teología moral, Tomo segundo, 1708, cn. 215.
} 
Agustín, profesada por los dominicos, que todo lo que poseyera aquel que había decidido abrazar la vida religiosa lo pusiera a disposición de su comunidad? ${ }^{67}$ De ese modo, la caridad era eminentemente sinónimo de fraternidad.

\section{FRAILES CARITATIVOS}

El apego a los bienes comunitarios así como el desprecio a la pobreza mendicante entre los frailes observantes en la época de la reforma respondía a las necesidades concretas de unas comunidades de intelectuales cada vez más numerosas y al sincero rechazo a formas de mendicidad que les parecían más afines al franciscanismo. Los frailes a su vez, sin conocer el desarrollo posterior que tendría su actitud, expresaron un tercer motivo que los invitaba a rechazar la pobreza en su vertiente mendicante, se trata de la asistencia a los pobres ${ }^{68}$.

Si bien la sociedad de finales de la Edad Media era estructuralmente pobre, la definición de la pobreza creaba, sin embargo, algunos problemas ${ }^{69}$. Normalmente el pobre había venido siendo identificado con el indigente de solemnidad, el pedigüeño vagabundo, cuya imagen es inseparable del paisaje urbano de la época. Existía, sin embargo, múltiples formas encubiertas de necesidad. La pobreza alcanzaba a muchos individuos sin tan siquiera respetar las fronteras de los grupos privilegiados. De hecho, gran parte de la población rural era pobre. Jornaleros, pequeños arrendatarios, propietarios y aparceros subsistían a menudo en condiciones límite de malnutrición y hacinamiento. Incluso en áreas económicamente avanzadas, como los Países Bajos, entre un 20 y un 40 por 100 de la población rural era considerada pobre ${ }^{70}$. La ciudad era también foco de pobreza encubierta. Muchos asalariados urbanos padecían grandes necesidades. La viudedad dejaba con frecuencia a las mujeres en situación precaria.

${ }^{67}$ Reguli beati Agustini episcopi, AGOP, XIV, Liber 1, f. 36v.

${ }^{68}$ Desde su fundación «la acción de los mendicantes para encontrar a los pobres y llevar a los laicos hacia ellos constituye un sector importante de su papel pastoral, desgraciadamente difícil de conocer con precisión, pero de cuya medida hablan los agravios formulados por los seculares», M. MoLLAT, Pobres humildes y miserables en la Edad Media, México, FCE, 1988, p. 117. Sobre la limosna, las obras de misericordia y la beneficencia eclesiástica en Castilla en el siglo XV véase, María del Carmen CARlé, «La iglesia y la sociedad castellana (siglo XV)», Anuario de estudios medievales, 15 (1995), pp. 384 y ss.

${ }^{69}$ Los pobres de la Edad Media podían llevar una vida austera, con un miedo constante al hambre y la enfermedad. Sin embargo, por lo general, esas personas no se encontraban completamente desamparadas; es decir, abandonados a su suerte, porque las redes de solidaridad de la sociedad medieval los acogían y ayudaban a sobrevivir. Véase, B. GEREMEK, La piedad y la horca. Historia de la miseria y de la caridad en Europa, Madrid, 1989.

70 Véase H. KAMEN, La sociedad europea (1500-1700), Madrid, 1986, pp. 184-199.

Hispania Sacra, LXI

124, julio-diciembre 2009, 483-512, ISSN: 0018-215-X 
La pobreza como peligro potencial de subversión social fue observada con preocupación creciente por las elites dominantes, especialmente después de los grandes estallidos de revuelta popular. Sin embargo, lo que más preocupó a la sociedad del momento fue la cantidad creciente de vagabundos, dedicados a la mendicidad, que eran mirados con un recelo creciente ${ }^{71}$. El miedo a los hambrientos errantes, a los que se consideró en forma creciente como elementos antisociales, se extendió a partir de la segunda mitad del siglo XV72.

Los dominicos reformados, haciéndose eco de los recelos generales, reconocieron que el aumento de la mendicidad creaba problemas. Advertían que muchos mendigos, «demandan muchas veces los que no lo han menester y hácense bellacos y vagabundos; (...) que condenan a los hombres que tienen algo porque dan a entender que no hay caridad para hacer bien, y ponen mil escrúpulos de conciencia en los tales, e infaman a los cristianos; (...) que como tantos andan de mil maneras, dejan de dar a los que han menester, y como piensan que son todos bellacos, a ninguno dan» ${ }^{73}$. Es más, condenaron a los frailes mendicantes porque con la cuestación privaban a los pobres de lo necesario. De hecho, en ese contexto, recibir limosna generaba serios problemas morales en algunos religiosos, resueltos a través del rechazo frontal o de otros modos más ingeniosos. Tal fue, por ejemplo, el caso de fray Juan Hurtado:

«Estando otra vez en la ciudad de Vitoria con la ocasión que ya dijimos de la acometida del Rey de Francia, se halló en la misma ciudad otra señora del reino de Toledo, Doña Ana de Castilla, muy gran bienhechora de la Orden y devotísima en particular del mismo fray Juan Hurtado, la cual entendiendo la pobreza que pasaban los frailes de Santo Domingo de Vitoria, y por que tuviesen alguna manera de ayuda para su necesidad y la de los huéspedes que en ella concurrían, le llevó en un lienzo cantidad de dineros para este efecto, y estando hablando con él en la iglesia se los dio, diciéndole que por que los frailes no se cansasen con él y con sus compañeros, le hiciese placer de tomar aquel lienzo que le daba. Tomólo el siervo de Dios, y volviendo la cabeza vio venir a una beata que muchas veces solía acudir a él a pedirle limosna. Llamola y díjola: a muy buen tiempo habéis llegado, tomad con que os remediéis. Y dióle el dinero sin destarlo ni mirarlo, honrando a un tiempo a la santa pobreza y ejercitando la virtud de la misericordia, sin reparar

\footnotetext{
${ }^{71}$ Una síntesis reciente sobre este tema referida a la sociedad castellana bajomedieval en Ricardo CóRDOBa DE LA LlaVe, «Marginación social y criminalización de las conductas», en M. A. LADERo QuesADA (coord.), El mundo social de Isabel la Católica. La sociedad castellana a finales del siglo XV, Madrid, 2004, pp. 293-322.

72 Una consecuencia de ello fue la aparición en el siglo XVI de un género literario de gran éxito y difusión que insistía en la falsedad, impudicia y falta de escrúpulos morales del lumpen urbano, organizado secretamente para cometer delitos. Hubo mucha exageración en la descripción de estos monipodios de vagabundos, a los que se suponía una sociedad paralela, con sus propias leyes, jerarquías y lenguaje, que conformaba una especie de submundo criminal. Véase C. Lis-H. Solby, Pobreza y capitalismo en la Europa preindustrial, (1350-1850), 1984, pp. 119-152.

${ }^{73}$ P. de LEÓN, Op. cit., p. 217.
} 
a que se podía quejar algún hábito vestido con afabilidad, que era el motivo que expresara la devota señora que le alargaba esta limosna» ${ }^{74}$.

Y es que el dinero, que el fraile observante normalmente despreciaba, debía ser destinado a sus verdaderos propietarios, los pobres.

No obstante, los dominicos estaban convencidos que la verdadera causa de la pobreza no era otra que el egoísmo de los que poseían. La desatención o la indiferencia con que muchos ricos condenaban a sus congéneres más humildes fueron fuertemente reprobadas por los frailes. Para Francisco de Vitoria esos tales jugaban con la salvación eterna. Lo dice expresamente en una de sus cartas a su íntimo amigo y antiguo colega, el Maestro en Sagrada Teología, fray Miguel de Arcos:

«En verdad que tengo por una señal de desaprobación que, en un año donde mueren nuestro prójimos y hermanos de hambre, tenga uno intento de hacerse rico. Pero cuanto al punto si peca mortalmente el que de nuevo encarezca el pan, en verdad que al que notablemente lo encareciese yo no sabría cómo le excusar» ${ }^{75}$.

Los frailes no podían estar de acuerdo con la criminalización del mendigo, porque de ese modo hubieran apoyado una actitud que consideraban antievangélica por parte de los ricos.

En cualquier caso, la preocupación en las sociedades europeas estaba plenamente justificada si se atiende a las abultadas proporciones de la pobreza solemne, es decir, la oficial y públicamente reconocida. Los extremos alcanzados por el fenómeno del vagabundeo y la mendicidad propiciaron la promulgación de disposiciones por los poderes públicos para limitar estas prácticas. Se trataba de medidas por lo general represivas que quedaron muchas veces sin efecto por las numerosas dificultades existentes para su aplicación. Las instituciones asistenciales, basadas en las ideas caritativas del Cristianismo medieval, resultaban por su parte totalmente insuficientes e inadecuadas para paliar un problema que las desbordaba por sus dimensiones ${ }^{76}$. La política de represión de la mendicidad y la vagancia afectó a la mayor parte de Europa occidental, resultando muy activa entre los años veinte y cuarenta del siglo XVI. Su dictado co-

${ }^{74}$ J. Cuervo, Op. cit., III, p. 561.

75 Citado por Vicente BeLtrán DE HeREdia, «Colección de dictámenes inéditos del maestro fray Francisco de Vitoria», La Ciencia Tomista, ${ }^{\circ} 128$ (1931), p. 171.

${ }^{76}$ Bajo la expresión genérica de hospital se conoció en el Medievo a distintos institutos de acogida a los pobres, mendigos, enfermos, peregrinos, etc. A finales de la Edad Media la red hospitalaria había adquirido un notable desarrollo, al que los frailes dominicos habrían contribuido notablemente. Véase, AA.VV., Actas das primeras Jornadas Luso-espanholas de Historia Medieval: A pobreza e a Assistencia aos Pobres na Península Ibérica durante a Idade Media, Lisboa, 1973; también los artículos publicados en Assistence et charité, Cahiers Fanjeaux, 13 (1978).

Hispania Sacra, LXI

124, julio-diciembre 2009, 483-512, ISSN: 0018-215-X 
rrespondió indistintamente a los poderes centrales y a las autoridades locales urbanas. El denominador común de esta política consistió normalmente en la prohibición de mendigar y la obligación de trabajar para todos los pobres que no estuvieran físicamente impedidos para ello.

Al mismo tiempo se intentaba racionalizar la beneficencia institucionalizando la caridad pública y centralizando los fondos destinados a atender las necesidades básicas de los menesterosos. Estas medidas representan en cierto modo un intento de reorganización de la asistencia con el que los poderes públicos intentaban sustituir en aras de una mayor eficacia las iniciativas privadas aisladas por una acción global socialmente rentable. La política represiva de la mendicidad coincidía, en líneas generales, con el discurso humanista sobre la pobreza. Tanto Tomás Moro como Erasmo de Rotterdam se pronunciaron contra la mendicidad.

Los reformadores castellanos compartieron en parte el pensamiento social de los reformadores europeos -católicos y protestantes- sobre todo en lo que se refiere a la idea del trabajo como deber y a la condena severa de la pereza. Alentados por una concepción integral del hombre, los frailes consideraron a la pereza como un mal moral grave: «El ocio arruina el alma, empobrece el cuerpo, hace al hombre lisonjero, parlero, novelero. El ocio, en fin, engendra la pereza, enemiga de todo virtuoso ejercicio» ${ }^{77}$. Su remedio era pues el trabajo.

Si bien los frailes asociaron la quietud perpetua al cielo (cuyo reflejo era el mismo convento) y el trabajo perpetuo al infierno ${ }^{78}$, la experiencia comunitaria les había demostrado que la actividad perseverante era una terapia ideal para curar la acidia e incluso a una de sus formas más dañinas, la depresión:

«Y los religiosos deben tener este cuidado, que después que salen del coro tengan algún ejercicio; y desque aquél anojare, otro y después otro, y así echarán la tristeza y pereza de este pecado. Mucho peligro tienen los religiosos que después de coro no tienen ejercicio de letra y otros saludables ejercicios a ellos y a los prójimos. Que cuanto se gana en el coro se pierde en vagar y en palabras vanas y ociosas (...) Así que no sólo el ejercicio de obrar es muy gran remedio para este pecado; pero la alteración y mudanza de los tales ejercicios ayuda mucho, porque el trabajo de un oficio alivia del otro, y el otro del otro, y así del trabajo hace quietud y de la quietud trabajo» ${ }^{79}$.

Sin embargo, a diferencia de los reformadores europeos, los observantes castellanos fueron unos predicadores incansables del asistencialismo hacia los

\footnotetext{
77 Melchor CANO, «La victoria de sí mismo», en Escritos espirituales, estudio preliminar y edición preparada por Vicente Beltrán de Heredia, Madrid, 1962, p. 46.

78 «Es de notar que tres reinos tiene Dios: uno es el cielo, y en este todo es quietud y sosiego; otro es el infierno, y en éste es todo trabajo mortal; otro es este mundo, y este como medio, participa de los dos extremos», P. de LEÓn, Op. cit., p. 244.

79 P. de LEÓN, Op. cit., p. 245.
} 
pobres y del igualitarismo social ${ }^{80}$. En su Guía del Cielo fray Pablo de León dedica numerosas páginas a la virtud de la caridad y dentro de ella al amor al prójimo, que desarrolla en cuatro temas: «Lo primero qué cosas son las que nos convidan a amar al prójimo; lo segundo qué cosas las que valen para ser amados de los prójimos; lo tercero de la manera del amar al prójimo; lo cuarto de diversas especies del amor del prójimo» ${ }^{81}$.

Ante todo, fray Pablo considera que el mandamiento del amor al prójimo igualaba las obligaciones de todos los cristianos, «le puede cumplir el pobre como el rico, el enfermo como el sano, el seglar como el religioso, el villano como el hidalgo, que no es menester comprar hacienda, ni mulas ni caballos, ni ir a Jerusalén para comprar este mandamiento». Deudor del pensamiento de los padres de la Iglesia, así como de los estoicos, este religioso instruye a sus lectores sobre los distintos modos de amar a los demás: como Cristo amó, o sea, con un amor que es gratuito y radical; como a nosotros mismos, en consecuencia, con un amor que es abnegado porque piensa en el bien ajeno; y como se aman los miembros de un cuerpo, con un amor que impulsa a compartir los bienes espirituales y materiales.

Llegado a este punto, Fray Pablo condena a todos aquellos que tienen bienes superfluos y no viven con lo necesario, porque «así como parece monstruo el hombre que no tiene los miembros proporcionados, así el cuerpo de la Iglesia parece sin proporción cuando uno es rico demasiadamente y otro muere de hambre. No es aquello según ley de Cristo»82. En consecuencia, el ejercicio de la verdadera caridad cristiana es la misericordia, «de manera que el que es caritativo es misericordioso y el que es misericordioso es limosnero. Porque la ejecución de la misericordia es limosna, y así el que tiene lo uno tiene lo otro, y el que no tiene uno de todo carece» ${ }^{83}$.

Entre los dominicos de la reforma la asistencia al pobre tenía, pues, un valor redentivo. Al fin y al cabo, para el cristiano el pobre es nada más y nada menos que Cristo ${ }^{84}$. Devotos de la pedagogía de la ejemplaridad, que movía a la imitación, los reformados se sentían obligados a educar con actos precisos a sus frailes y a la sociedad en general. En 1521 fray García de Loaysa, Maestro General de la Orden, ordenaba al prior del Convento de San Esteban «que, si le parecie-

\footnotetext{
${ }^{80}$ Hay que decir que si bien los dominicos españoles lograron componer una teoría de la defensa del pobre, en Europa el pobre fue objeto de atención de todas las órdenes mendicantes. Véase, Sylvain PIRON, «Prêts charitables et opérations capitalistes dans l'éthique franciscaine des contrats monétaires», en L. Fontaine-G. Postel-Vinay-P. L. Rosenthal-P. SeRVAis (dir.), Des personnes aux institutions. Réseaux et culture du crédit du XVIe au XXe siècle en Europe, Louvain-la-Neuve, 1997, pp. 11-27.

${ }^{81}$ P. de LEÓN, Op. cit., p. 182.

82 P. de LEÓN, Op. cit., p. 196.

${ }^{83}$ Ibíd., p. 216.

${ }^{84}$ Ibíd., pp. 217-223.
}

Hispania Sacra, LXI

124, julio-diciembre 2009, 483-512, ISSN: 0018-215-X 
se conveniente, dé a los indigentes la cantidad de medio ducado al mes de las ganancias del convento, bien en trigo, bien en metálico, si en verdad considerase que se debe gastar una suma mayor en los pobres, cosa que no quiero que se haga sin el consentimiento de los superiores (padres). Quien actuase de manera contraria, que sepa que será considerado reo de culpa tanto como si incidiese en un delito de robo» 85 .

La norma tuvo su efecto y la comunidad salmantina se encargó de recoger la memoria de la acción caritativa de los frailes. Durante el priorato de fray Domingo de Montemayor (1528 a 1530), por ejemplo, «fue el caso que habiendo una grande hambre en esta ciudad de Salamanca, mantuvo a costa de su convento ochocientos pobres todo el tiempo que duró la necesidad, que no fue poco. Y cuando vio que la hacienda del Convento no bastaba, excitó con su ejemplo a los religiosos todos a que partiesen de su pobre comida con los pobres, los cuales a imitación de su Prelado se contentaban con muy poco, dando todo lo demás a los pobres» ${ }^{86}$.

En España, a raíz del continuo incremento de la mendicidad, iba a estallar una seria disputa sobre la pobreza y la asistencia institucional a los pobres, durante la cuarta y quinta década del siglo XVI. En general, las medidas contra la mendicidad habían sido algo más suaves que en otros países de Europa, en el sentido de reglamentar más que de prohibir. Para suscitar un cambio de actitud, el humanista Luis Vives, en su obra De Subventione Pauperum (Brujas, 1526), propuso un programa detallado de acción social que incluía la prohibición de mendigar, el trabajo obligatorio para los indigentes, la centralización de la asistencia y la creación de escuelas para niños pobres. El prior de San Esteban de Salamanca, fray Domingo de Soto, heredero de la experiencia de las comunidades observantes y del pensamiento que éstas desarrollaron respecto al ocio, el trabajo y la mendicidad, desarrolló una reflexión de respuesta a las orientaciones humanistas. En su Deliberatio in causa pauperum (1545), responde indirectamente a las tesis de Vives ${ }^{87}$.

No debe verse en Soto un espíritu reaccionario, contrario a cualquier cambio en este tema. Nos encontramos con un defensor de la dignidad de los pobres, particularmente atento y crítico frente al sentido represivo que había en las reflexiones humanistas y en las políticas sociales que caracterizaban tanto a las ciudades libres como a los Estados absolutos ${ }^{88}$. Según el teólogo salmantino, la

\footnotetext{
${ }^{85}$ Ramón HeRnÁndeZ, «Texto de las ordenaciones de García de Loaysa», A. D., XVIII (1997).

86 J. CUERVo, Op. cit., III, p. 569.

87 Ángel Martínez CASAdo, «Los Pobres y Domingo de Soto», Cuadernos Salmantinos de Filosofía, vol. XXX (2003), pp. 629-645.

88 Véase, J. M. GARRÁn MARTínez, La prohibición de la mendicidad: la controversia entre Domingo de Soto y Juan Robles en Salamanca (1545), Salamanca, 2004.
} 
situación de pobreza no es de por sí de vileza, sino positiva. Sin negar la necesidad de que el Estado legisle en esta materia, Soto sostiene la legitimidad de las prohibiciones unidas a las nuevas legislaciones (prohibición de moverse del lugar, de mendicidad en algunos lugares, etc.) sólo cuando la situación económica es tal que permita a los pobres un sustento sin tener que recurrir a la limosna. Mientras esta situación no llegue, la mendicidad debe ser tolerada como mal menor.

Soto se declara contrario también al uso de presiones de carácter religioso con los pobres, como la obligación de confesarse para conseguir el permiso de mendigar. «El príncipe que posee el poder político tiene el derecho y la autoridad de impedir la mendicidad a condición de que provea de otro modo a los pobres comida y vestido y todo lo que necesitan en proporción a su condición» (Deliberado, 1, 11, c. 2). La curiosidad de los ricos sobre las culpas morales de los pobres es sacrílega, y, cuando los ricos llegan a obligar a los pobres a la confesión o a otras condiciones para poder recibir la limosna, no hacen otra cosa que condenarlos indirectamente a muerte ${ }^{89}$.

En realidad el pensamiento de Soto era deudor de la actitud caritativa de los superiores y frailes del convento de San Esteban hacia los pobres frente a las cíclicas dificultades económicas que conoció la ciudad de Salamanca entre 1528 y 1560. Francisco de Vitoria y Domingo de Soto hubieron de contribuir varias veces para la obtención de pan para la población universitaria. En 1539, en que la necesidad fue apremiante, Domingo de Soto marchó a Toledo, de donde trajo para la academia 5.000 fanegas de trigo gracias a la intervención del cardenal Tavera. Francisco de Vitoria, que tenía el cargo entonces de depositario, se encargaba de pagar a los transportistas. $\mathrm{Al}$ año siguiente, en el mes de mayo, dos claustros de diputados le encargan a Vitoria dos misiones parecidas ${ }^{90}$.

Si bien éstas fueron intervenciones, si se quiere, para atender a una porción de la población privilegiada-como pueden ser considerados los estudiantes- en

89 Otros autores, como Juan de Medina, Miguel Giginta y Cristóbal Pérez de Herrera, defendieron, por el contrario, la necesidad de distinguir entre los verdaderos pobres y los fingidos, obligando a estos últimos a trabajar. Giginta y Pérez de Herrera propusieron también el control planificado de la pobreza (en el caso de Pérez de Herrera también de la prostitución) a través de casas de misericordia o albergues de pobres, que debían ubicarse en las principales ciudades del país y garantizar la aplicación al trabajo de los mendigos físicamente capacitados. Para Bartolomé Bennassar, este debate sobre la pobreza constituye «el testimonio de la coexistencia en España de dos mentalidades antagónicas, una orientada hacia la transformación del país a través de la organización y el trabajo, la otra tendente simultáneamente a la preservación del orden social y al ejercicio anárquico de las pulsiones individuales. La que se impuso (...) fue la segunda», Ángel GALINDO GARCíA, «La lucha contra la pobreza en el siglo XVI», Cuadernos Salmantinos de Filosofía (Salamanca), vol. XXX (2003), pp. 589-613.

90 Véase, Ramón Hernández, Francisco de Vitoria. Vida y pensamiento internacionalista, Madrid, 1995, pp. 96-97.

Hispania Sacra, LXI

124, julio-diciembre 2009, 483-512, ISSN: 0018-215-X 
1544 tuvieron los frailes ocasión de ayudar a los más miserables. En esa ocasión Domingo de Soto integró la comisión encargada «para la examinación de los pobres que en la dicha ciudad hay» ${ }^{91}$. Unos años más tarde, cuando Melchor Cano (1557-59) era prior del convento de San Esteban, se produjo algo similar. Los cronistas del convento dicen que Domingo de Soto, «viendo que perecían los pobres, predicaba públicamente para persuadir a todos los que podían se moviesen a socorrer necesidad tan grande. Juntábanse después de haber predicado con el corregidor y algunos caballeros, y andaba a pedir limosna por toda la ciudad, y lo que juntaban, se daba a los pobres, gastándose en su alimento y consuelo». Podemos ver que no se había dejado todo a la mendicidad testimonial, escasamente institucional, pues asistía el corregidor y posiblemente algunos regidores, para recaudar fondos.

En el mismo convento de los dominicos se estableció un sistema asistencial bastante organizado:

«aplicáronse a sustentar con sus hombros el gran peso de necesidad tan grave dos gigantes de aquel siglo, fray Melchor Cano y fray Domingo de Soto, y obraron estos dos padres y todo el convento en aquella ocasión harto empeñado, se tomaron mil ducados a censo para poder aliviar a los pobres y socorrerlos con mucha liberalidad, comos e hizo. Hizo el padre prior que se escribiesen todos los pobres que habían de ser socorridos, y para que en esto hubiese más orden y concierto, había personas señaladas en cada parroquia, por cuya cuenta estaba venir todos los días al convento y llevar el pan necesario para socorrer cada uno a los pobres que vivían en su parroquia, dando a cada uno con grande abundancia lo necesario. Fuera de esto, se pusieron en la iglesia dos mesas, una para hombres y otra para mujeres, y todo el tiempo que duró el hambre, se dio de comer en ellas a todas cuantas personas venían poniéndoles en la mesa todo lo necesario. Esto hacía el convento poniendo la comunidad mucho y ayudando los particulares todos con sus raciones... Accedieron muy libremente todos los ciudadanos, cada uno del modo que podía, al socorro y alivio de los pobres, y lo que se juntaba, se gastaba en el convento con los pobres del modo que dijimos» ${ }^{92}$.

La espiritualidad de los dominicos reformados consideró a los pobres como un medio redentivo. Impulsados por el ejemplo de sus superiores, la actuación misericordiosa de los frailes, que se tradujo en el ejercicio de la limosna, finalizó por dar origen a un pensamiento social asistencialista y a una renovación profunda de la Teología ${ }^{93}$. En efecto, la actividad docente de Francisco de Vito-

91 Claustro del 23 de febrero de 1544. Véase, V. Beltrán DE Heredia, Domingo de Soto. Estudio biográfico documentado, Madrid, Biblioteca de teólogos españoles, 1960, p. 90.

92 J. Cuervo, Op. cit., I, pp. 387-388. Véase también, Ángel MartínEZ CASAdo, «Derechos de los pobres según Domingo de Soto», en L. MÉndEz Francisco (coord.), La ética, aliento de lo eterno. Homenaje al profesor Rafael A. Larraneta, Salamanca, 2003, pp. 173-187.

93 Sobre la renovación de la teología en la «escuela de Salamanca» véase, J. BELDA PLANS, La Escuela de Salamanca y la renovación de la teología en el siglo XVI, Madrid, 2000, pp. 207 y ss. 
ria, Domingo de Soto, Melchor Cano en Salamanca, a partir de 1530 y hasta finales del siglo XVI, no fue otra cosa que una exitosa expresión de la tenaz preocupación de los frailes reformados por integrar en un mismo conjunto la teología y la vida cristiana.

La Teología Moral renovada que se impartió en las aulas universitarias de Salamanca a partir de 1530 fue en muchos aspectos deudora de la experiencia religiosa y de la espiritualidad de los frailes reformados. Y es que los frailes, no obstante se hubieran despojado de todo bien material, estaban obligados a ser enteramente solidarios. No tenían excusas para escapar a esa obligación. Y si no se podía prestar una ayuda material siempre quedaba la asistencia espiritual. La intercesión de los frailes, otro capítulo de la historia socio-cultural de los religiosos, se transformó en el mejor modo de ser misericordiosos con sus contemporáneos.

En definitiva, en el alba de la Edad Moderna, la caridad y la piedad practicada por los religiosos pasaron a ser algo más que virtudes complementarias, ya que el cuidado de un enfermo o de un pobre no dejaba de ser un acto de devoción. 